\title{
Extensive larval dispersal and restricted movement of juveniles on the nursery grounds of sole in the Southern North Sea
}

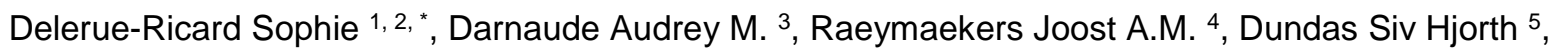 \\ Skadal Julie ${ }^{5}$, Volckaert Filip A.M. ${ }^{1}$, Geffen Audrey J. 5,6
}

${ }^{1}$ Laboratory of Biodiversity and Evolutionary Genomics, KU Leuven, Charles Deberiotstraat 32, B-3000

Leuven, Belgium

2 Institute for Agricultural and Fisheries Research, Ankerstraat 1, B-8400 Oostende, Belgium

${ }^{3}$ Center for Marine Biodiversity, Exploitation \& Conservation, CNRS, University of Montpellier, Ifremer, IRD, F-34095 Montpellier, France

${ }^{4}$ Faculty of Biosciences and Aquaculture, Nord University, N-8049 Bodø, Norway

5 Department of Biological Sciences, University of Bergen, PO Box 7803, N-5020 Bergen, Norway

${ }^{6}$ Demersal Fish Group, Institute of Marine Research, PO Box 1870, Nordnes, N-5817 Bergen, Norway

* Corresponding author : Sophie Delerue-Ricard, email address : Sophie.DelerueRicard@kuleuven.be

\begin{abstract}
:
Connectivity between spawning and nursery grounds influences the colonization, replenishment and resilience of populations of marine organisms. Connectivity rate, measured as the exchange of individuals between spawning and nursery grounds, is therefore a crucial determinant of stock size. However, connectivity of early-life stages is hard to explore due to sampling limitations and insufficient knowledge on potential larval sources. Here we present new insights into pre- and post-settlement dispersal of the common sole (Solea solea L.) at a spatial scale of 5-500 km in the Southern North Sea. Patterns at a scale of $<100 \mathrm{~km}$ were considered local, whereas patterns further than $100 \mathrm{~km}$ were considered regional. Multi-elemental signatures of the otolith edge of 213 juvenile sole were used to discriminate at $79 \%$ of overall accuracy three main nursery grounds in the Southern North Sea, namely UK coast, Belgian coast and Dutch Wadden Sea. Interregional differences in otolith composition (especially for $\mathrm{Mg}, \mathrm{Mn}$ and $\mathrm{Ba}$ ) suggest that sole migration following settlement is limited in the Southern North Sea. Elemental signatures of the same fish indicated mixing during larval dispersal. Each nursery ground recruited an important mix of juveniles from three of the four chemically distinct natal sources identified from the larval otolith signatures. However the percentage of correct regional re-assignment varied from 67 to $80 \%$ with a maximum in the Wadden Sea. The results contributed to the validation of biophysical models of larval drift. Our findings support decision making for both fisheries management and marine spatial planning at the national and European level.
\end{abstract}




\section{Highlights}

- In the North Sea, juvenile otolith signatures differ at the regional scale $(100 \mathrm{~km})$. Movement appears to be limited once the juveniles have reached a nursery ground. Local nursery areas receive larvae from four chemically distinct natal sources. Mixed larval contributions to nurseries point to an extensive larval dispersal.

Keywords : Connectivity, Early-life history, North Sea, Otolith elemental composition, Trace elements, Solea solea 


\section{Introduction}

Connectivity, i.e. the exchange of larvae, juveniles or adults among geographically separated groups (Palumbi 2004), drives colonization, enables replenishment and promotes resilience of populations to disturbances (Botsford et al. 2001, Cowen et al. 2007). In marine organisms with a planktonic larval phase, connectivity between spawning and nursery grounds is one of the main drivers of recruitment (Harden-Jones 1968, Rijnsdorp et al. 1992). Spawning ground origin and dispersal pathways may impact the quality of the larval pool and thereby modu'?te juvenile survival (Pineda et al. 2007, Shima \& Swearer 2010). In addition, anthr 1009 эnic activities or environmental

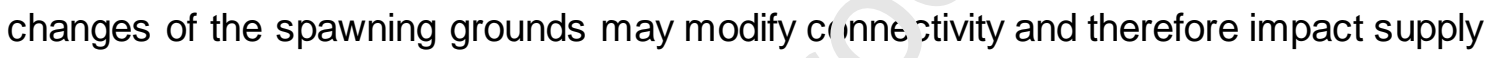
to the nursery grounds (Lacroix et al. 2018). : herefore, understanding connectivity at the scale of dispersal is paramount to : sply adapted management measures for metapopulation persistence (Batista et al. 2015, Krueck et al. 2017). Connectivity may be more important than habitat qualitv : $r t^{\dagger}$ ie design of Marine Protected Areas (MPAs, OSPAR 2013). This information,$\epsilon$ ds the increasing calls for prioritizing locations that are self-replenishing, interconne ed, and/or important larval sources (Krueck et al. 2017). However, while the ethiency of MPA positioning depends on the quality of input data regarding fish dispers $l \mathbb{1}, \mathrm{E}$-tista et al. 2015), data on fish movements at the larval and juvenile stages rem in sifficult to compile.

The distributı? and dispersal of flatfishes have been investigated extensively, both through semnling and tagging (Burt \& Millner 2008, Dorel et al. 1991, Gibson 2015), the $a_{1}, l_{y}$ ic of life history traits (Randon et al. 2019), and the use of biological tags like otolith nicrochemistry (Darnaude \& Hunter 2018, Hunter et al. 2003). The ecology of the common sole (Solea solea L., 1758; Soleidae) has been particularly well studied (Amara et al. 2007, Fincham et al. 2013, Marchand 1991). The species mainly spawns from March to June along the shores of the North East Atlantic Ocean (Ellis et al. 2012, Rijnsdorp et al. 1992). After hatching, the pelagic larvae drift in the water column for about one month before settling in a shallow coastal or estuarine nursery (Russell 1976, van der Land 1991). Estimates of larval dispersal range between 80 and $300 \mathrm{~km}$ depending on the spawning ground, with an average drift of about $150 \mathrm{~km}$ as estimated from biophysical modeling and genetic markers (Dorel et al. 1991, Kotoulas et al. 1995, Lacroix et al. 2013). Yet, empirical evidence of connectivity between sole spawning and nursery grounds is scarce (Morat et al. 2014). Similarly, little is known about the movement of juvenile sole in the months following settlement. Population 
structuring among the nursery grounds and the adult feeding grounds of sole has been characterized through otolith chemistry along the coasts of the Atlantic Ocean and the Mediterranean Sea (Leakey et al. 2009, Tanner et al. 2012). However, this information is limited in the North Sea (Cuveliers et al. 2010). The distribution of sole nurseries tends to be continuous along the North Sea coasts (Ellis et al. 2012, Rijnsdorp et al. 1992) and biophysical modeling suggested a mixed contribution of several spawning grounds to most juvenile habitats (Lacroix et al. 2013, Savina et al. 2010). However, a recent shift was observed in the distribution of North Sea sole (Engelhard et al. 2011),

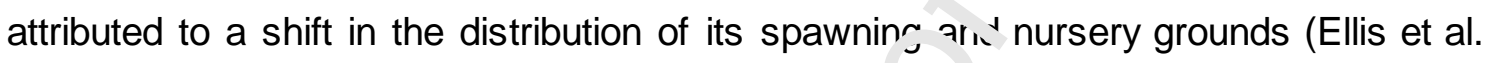
2012). In the future, a longer larval dispersal due tc $\sim r$.der temperatures experienced by earlier hatched larvae could also impact the cistrit ution (Lacroix et al. 2018). These recent changes, probably caused by both = lin $n_{1}$ tic and fishing pressures, call for a focus on the early-life connectivity of sole $1+\ldots$ area. Understanding the patterns of dispersal and their causes is of primar, i, nportance because climate change modeling at the level of the North Sea predicts ai. increase in larval recruitment for some fish species. Strong regional differ $\lrcorner n c$ s among nursery grounds may characterize the shifts in larval recruitment (Lacroix c ${ }^{+}$al. 2018).

This study measures :0 11 zctivity between the spawning and nursery grounds of sole in the Southern Nort. Sea using otolith microchemistry. Otoliths are calcified structures in the innt. ear which grow with regular increments and incorporate timedelimited information ( Jampana 1999). For example, when juvenile fish settle on the nursery ground thi high metabolic impact of metamorphosis is recorded in otolith growth (De Fintual et al. 2000), with a distinct separation between increments deposited duriry the pelagic larval stage from those formed after benthic settlement. Revealing chemical differences between pre- and post-settlement regions of the otolith may inform about dispersal at the larval stage but also about fish movements within and between nursery ground areas. The chemical composition of otoliths has already been proven effective to infer differences in spawning origin and to discriminate among nursery grounds (e.g., Gibb et al. 2017, De Pontual et al. 2000). Although small-scale migration patterns in coastal zones remain challenging to trace with otolith microchemistry because of the short residence time of water (Tanner et al. 2012), estuaries often carry strong chemical signals, at small and large spatial scales (Gillanders \& Kingsford 2003, Di Franco et al. 2012, De Pontual et al. 2000). 
The North Sea is particularly suited for otolith elemental studies of fish spatial origin and movement because of its chemistry. The area is one of the most polluted seas of the world (Grizzetti et al. 2017). Its coasts receive runoff water that carries the chemical signature of local river catchments (De Witte et al. 2016, Hamer et al. 2006). Onshoreoffshore gradients in relation to the distance from riverine input are observed for certain elements. We focused on seven coastal areas used as nursery ground by sole in the Southern North Sea, spread along the UK, Belgian and Dutch coastlines. Distances between sampling locations range from 5 to $500 \mathrm{~km}$. We tested whether the otoliths of juvenile sole from these sampling locations crild discriminate multi-elemental signatures. The composition of the larval part of the sto'.ths was also used to estimate the number of chemically distinct spawning gonurds (further referred to as natal sources) that supply each location with larvm $: / / e$ then quantified the extent of local $(<100 \mathrm{~km})$ pre- and post-settlement dispers -' 'رy comparing the elemental signatures from three key life history periods: +'. ic pelagic larval phase, the few weeks after metamorphosis (post-settlement), ar $d_{1} L_{1}=$ tew weeks on the nursery ground preceding capture.

\section{Material and methoce}

\subsection{Sample collection}

Age-0 and agf-1 sole belonging to five cohorts, hereafter referred to as settled juveniles, wert runected between 2006 and 2016 on three major Southern North Sea nursery grouniu (Ellis et al. 2012, Rijnsdorp et al. 1992) which correspond to our 'sampling regions' (Fig. 1 and Table 1): (1) the UK nursery ground (UK), sampled near Sizewell power station and in the Thames Estuary, (2) the Belgian nursery ground (BE), sampled at four locations: B1, B2, B3, and B4, which includes juveniles caught at Zandvliet (ZANj07) in the Scheldt Estuary, and (3) the Wadden Sea nursery ground (WA) along the Dutch coast (sampled at Balgzand (BALj06) and in the Ems-Dollard Estuary. At all sites, a $3 \mathrm{~m}$ beam trawl with cod end mesh size of $10 \mathrm{~mm}$ was used to catch the fish. Sampling covered several years but only two nursery grounds (B3 and B6) were sampled in consecutive years (in 2013-2014). At all sites, juvenile sole were captured between the end of May and October, except for the Sizewell power station which was sampled in March. Water temperature was measured on site on the day of 
sampling. All fish were measured and weighed (standard length to the nearest $\mathrm{mm}$ and total weight to the nearest g; Suppl. Fig. 1) and kept frozen until dissection.

In order to have a sufficient number of fish per site to enable discrimination, nearby nursery grounds in each region were grouped, resulting in seven geographically distinct nursery areas, hereafter referred to as 'sampling locations'. The closest sampling locations were $5 \mathrm{~km}$ apart (along the Belgian coast) and distance between the furthest sampling locations was $500 \mathrm{~km}$. Therefore, patterns at a scale of less than $100 \mathrm{~km}$ (i.e. the full extent of the Belgian coastline) v: are considered local, whereas patterns at a scale wider than $100 \mathrm{~km}$ (i.e. amor $x$ th ; four sampling regions) were considered regional.

\subsection{Otolith extraction and preparation}

All equipment for otolith extract.vin and handing was acid washed in a $10 \%$ nitric solution prior to use. Only the $\epsilon_{.}{ }^{+}$sagittal otoliths were used in this study because the chemical composition, shape and mass of otolith is asymmetric in flatfish (Mille et al. 2015, Mérigot et al. 2007). Cu liths were extracted and weighed to the nearest 0.005 $\mathrm{mg}$ and fish age-class ( $\iota$ or 1 ) was determined by macroscopic examination. To remove any surface :onlumination, the otoliths were rinsed with distilled water and $0.1 \%$ nitric acid, and . onicated in vials filled with ultrapure water. Otoliths were then mounted in mo'ss, sovered with epoxy resin and transversely cut through the nucleus using diamonc hlades mounted on an ISOMET Buehler precision saw. The nucleus was exposed ... thin sections on one side by polishing the otoliths cuts. They were sonicated in ultrapure water for a second time, left to dry for $24 \mathrm{~h}$ under a class 100 laminar flow hood and glued on a glass slide for later analysis. Otoliths from different sampling locations were mixed randomly on each slide to minimize session effects.

\subsection{Otolith elemental analysis}

Otolith elemental composition was determined by laser ablation inductively-coupled plasma mass spectrometry (LA-ICPMS) using a Nu Instruments ATTOM ES High resolution ICP-MS coupled to a Resonetics RESOlution M-50 193 nm excimer laser ablation system with helium as carrier gas. Otolith material was ablated along the same 
transect for all fish from the core to the dorsal edge. The laser beam diameter was set at $64 \mu \mathrm{m}$ and analyses were made with an energy of $90 \mathrm{~mJ}$ (Attenuated $50 \%$ ), a frequency of $7 \mathrm{~Hz}$ and at a speed of $5 \mu \mathrm{m} . \mathrm{s}^{-1}$. A total of 26 isotopes were measured (Suppl. Table 1). For some elements, two isotopes were initially quantified to test for possible mass interference. Precision and accuracy were measured using National Institute of Standards and Technology (NIST) 610, FEBS and NIES standards of known composition. Standards were measured at least every 15 measures for accuracy and precision calculations. NIST 612 was I sed for calibration. The chemical signal was processed with lolite software (Paton et $-1<211$ ). Data below the Limit of Detection (LOD $=3 \times$ standard deviation of the blann - 'nstead et al. 2015) were set to zero (average missing percentage per elemen+ $、$ 'as $2.1 \pm 3.7 \%$; Suppl. Table 1). After visual inspection for outliers, missing val'ns, interference between isotopes and precision and accuracy (Suppl. Table 2), the r.ne most reliable elements $\left({ }^{23} \mathrm{Na},{ }^{26} \mathrm{Mg}\right.$, ${ }^{55} \mathrm{Mn},{ }^{63} \mathrm{Cu},{ }^{66} \mathrm{Zn},{ }^{85} \mathrm{Rb},{ }^{86} \mathrm{Sr},{ }^{137} \mathrm{Ba},{ }^{208} \mathrm{P}_{\nu}^{\prime}$, see Panfili et al. 2002) were kept for further

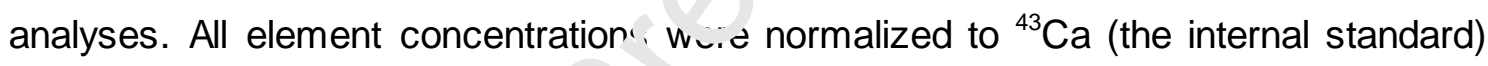
and expressed in $\mu \mathrm{mol} \mathrm{mol}^{-1}$ fo' $\mathrm{Mc} \mathrm{Ca}, \mathrm{Mn} / \mathrm{Ca}, \mathrm{Cu} / \mathrm{Ca}, \mathrm{Zn} / \mathrm{Ca}, \mathrm{Rb} / \mathrm{Ca}$, in $\mathrm{mmol} \mathrm{mol}^{-1}$ for $\mathrm{Na} / \mathrm{Ca}, \mathrm{Fe} / \mathrm{Ca}$ and $\mathrm{Sr} / \mathrm{Ca}$, and in $\mathrm{pn}, \mathrm{\nu l} \mathrm{mol}^{-1}$ for $\mathrm{Pb} / \mathrm{Ca}$.

\subsection{Selection of early lif: hisiory zones and signal processing}

Primary increments I. ave been validated to be daily in larval and juvenile sole, and characteristic $m$ air s sepresent hatching, first feeding and metamorphosis (Amara et al. 1998, Lagarcire i Troadec 1997, Paoletti, pers. comm.). Three zones along the transect analy $\sim d$ were isolated to measure the chemical signal at different life history stages: (1) the 'larval' area just outside the core, reflecting the signature of the fish natal source, (2) the 'post-settlement' portion just after the metamorphosis mark reflecting the signature of the nursery ground colonized at benthic settlement, and (3) the 'otolith edge', i.e. the portion laid down during the last weeks before capture and reflecting the signature of the sampling location (Fig. 2). On average, the three zones were all $77 \pm 5 \mu \mathrm{m}$ long, which corresponds to 2-3 weeks of signal integration depending on fish age and growth rate (Lagardère \& Troadec 1997). They were respectively positioned at $50 \mu \mathrm{m}$ from the edge of the otolith, $30 \mu \mathrm{m}$ from the settlement mark and $50 \mu \mathrm{m}$ from the primordium (as the core area is $40 \pm 10 \mu \mathrm{m}$ long for sole, Lagardère et al. 1995). Measurements for identifying the life history periods were made on images captured using a Leica M125 microscope (objective 10x). 


\subsection{Data analysis}

\subsubsection{Spatio-temporal variation in elemental signatures on the nursery grounds}

The concentrations of the nine elements retained for this study did not meet assumptions of normality and homoscedasticity (Shapiro-Wilk and Bartlett tests) even after $\log _{10}$ transformation. Therefore, the temporal stability in the chemical signal was tested for the two sites sampled in 2013 and 2014 ( $\mathrm{B}^{-}$' and B6) through Wilcoxon tests and correction of the significance levels using a ser,amini-Hochberg correction for multiple testing. A MANOVA between multi-elf،ाl ntal fingerprints, time (year) and space (sampling region) was performed to resı the effect of space and time on elemental composition. Spatio-temporal va ratı $n$ associated with the multi-elemental signature at the sampling location was als visually assessed using a Principal Component Analysis (PCA). The effec $r$, ish length was investigated using Spearman rank correlation for each eleme-t $w^{\text {th }}$.hin each sampling region and location. Spatial variation in otolith signature wa i ivestigated using the Kruskal Wallis test (for single elements) followed by a pos: hoc comparison (Dunn test) to determine which elements contributed to the differe' $c$, among sampling locations. For this, we used the chemical signatures rec $\mathrm{v}^{\mathrm{v} e u}$ on the edge of the otolith for all fish, as they reflect the time and location of $c=$ otur?

Spatial discı 'ni' lation success among sampling locations (based on otolith edge signatures) : ' $\mathrm{AS}$ ᄀ/sr assessed using the random forest (RF) algorithm (Breiman 2001). $\mathrm{RF}$ requires no c priori on the distribution of the data and allows to significantly improve discrimination power when using otolith multi-elemental data (Mercier et al. 2011). Details of the method are available in Tournois et al. (2017). First, all possible combinations of elements out of the nine retained were tested to identify the combination allowing to achieve the best discrimination accuracy using RF. For this, data were centered and reduced to give the same weight to all elements in the spatial discrimination. To avoid circular reasoning, $75 \%$ of the signatures were randomly selected to build and "train" each possible combination of elements ('RF classifier') while the remaining $25 \%$ were used to test its reliability in re-assigning signatures to the correct origin. In each case, 500 classification trees and 1000 iterations were used and minimum, maximum and average overall discrimination accuracies were calculated to assess the value of each RF classifier for spatial discrimination as in Tournois et al. 
(2017). Once the list of elements leading to the best discrimination (i.e. the optimal RF classifier) were identified, classification accuracies and the True Skill Statistics (TSS, Allouche et al. 2006) were calculated for each sampling location. The accuracy represents the total number of fish correctly reclassified to their sampling location while TSS also accounts for true negative prediction. TSS ranges from -1 to +1 , where +1 represents $100 \%$ of correct prediction of presence or absence in a given habitat, 0 indicates random predictions and -1 indicates $100 \%$ incorrect predictions. Finally, the contribution of each element to the spatial discrimina tion was assessed by calculating the mean decrease in global Gini Index (Gl, Breimar ? $v_{\imath 1}$ ) after its removal from the optimal classifier. Gl ranges from 0 (when all elem, ntr equally contribute to the total discrimination) to 100 (when a single eleme, $+c$ sntributes to $100 \%$ of the total discrimination). The higher the decrease in $\mathrm{C}^{\prime} w$ :'en one element is removed from the classifier, the more that element is essentia. $f_{-}$, the discrimination. The percentage of assignment was calculated, with 10 , terations, assigning fish to each sampling location, including the capture locitici., based on their edge signature. Average percentage of re-assignment $w^{\prime}$ is + ien calculated for each sampling location and each sampling region.

\subsubsection{Investigation of po en inl migration after settlement}

Once validated bast ${ }^{\prime} 0.1$ otolith edge signature (see section 2.5.1), the optimal RF classifier was ur $=\downarrow \backsim$ dentify the nursery area most likely occupied by the juvenile sole just after $m_{1}+a_{1} \cdots$.phosis. This also enabled detection of any migration among sampling locatin's after the benthic settlement. For this, the optimal RF classifier was trained with all otolith edge signatures and used to assign each otolith post-settlement signature to its most likely location of origin (among the seven sampled). The percentage of assignment was calculated, with 100 iterations, assigning fish to each sampling location, including the capture location, based on their post-settlement signature. Average percentage of re-assignment was then calculated for each sampling location and each sampling region.

\subsubsection{Natal sources}


Clustering analysis was performed on the otolith region corresponding to the larval phase (see section 2.4) to estimate the number of larval origins (hereafter referred to as 'natal sources') contributing to the focal nursery grounds as well as any connectivity patterns between them. Larval clusters were defined based on the material outside the core area as the core is under maternal influence and enriched in some elements associated with physiological changes rather than with environmental signals (e.g. Ruttenberg et al. 2005, Brophy et al. 2003). Larval clusters were defined using Euclidian distance by unsupervised K-means clustering (i.e. without taking sampling location into account). The optimal number of clinter was determined using the NbClust package in $R$ (Charrad et al. 2014) whic: r smpares 30 different types of clustering indices. Data was centered and red' ' $\mathrm{C}$ 'd $\mathrm{r}$ ecause k-means clustering tends to give more weight to large clusters and is 'ns likely to identify small larval sources due to its sphericity assumption.

\section{Results}

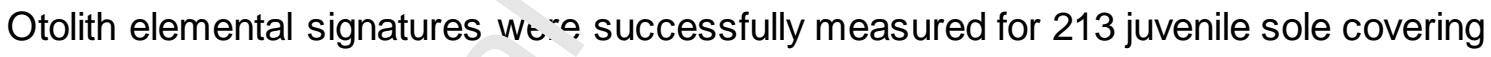
the seven sampling locatio, is a nd three regions (Table 1). Nine elements ( $\mathrm{Na}, \mathrm{Mg}, \mathrm{Mn}$, $\left.\mathrm{Cu}, \mathrm{Zn}, \mathrm{Rb}, \mathrm{Sr}, \mathrm{Ba}, \mathrm{P}_{\mathrm{n}}^{\prime}\right)$ were regularly detected at all sampling locations with high precision and accuracy: they were retained for statistical analyses (Suppl. Table 3a). The mean percenc $x$ e ff data below the LOD was $\leq 4 \%$ for all elements, except for $\mathrm{Li}$ (57\%), Co (61\%) C $\times(96 \%)$ and $\mathrm{Pb}(11 \%)$, the first three of which were excluded from further analyses 'Suppl. Table 1). The relative standard deviation for NIST 612 was $\leq 6$ for most elements, with the exception of $\mathrm{Li}$ (15), $\mathrm{Na}$ (8), $\mathrm{Mg}$ (7) and $\mathrm{Fe}$ (10). The recovery rates and relative standard deviations of other standards are listed in Suppl. Table 2. Correlations between fish length and otolith element concentrations within regions or locations varied in no particular direction and were rarely significant after correction for multiple testing (Suppl. Table 4) indicating no significant effect of fish length on the otolith concentrations measured. 
Discrimination accuracy among all sampling locations was highest (79\%) when eight of the nine elements ( $\mathrm{Na}, \mathrm{Mg}, \mathrm{Mn}, \mathrm{Cu}, \mathrm{Rb}, \mathrm{Sr}, \mathrm{Ba}$ and $\mathrm{Pb}$ ) were included in the $\mathrm{RF}$ classifier. Hence, most elements are informative for discriminating among the seven sampling locations in the Southern North Sea (Fig. 3). Using this optimal RF classifier, the accuracy of correct assignment for otolith edge signatures was $>80 \%$ for the UK and Wadden Sea nursery grounds, but slightly lower for those along the Belgian coast where the average classification accuracy was $75.8 \pm 9.9 \%$ (Table 2 ). TSS were all positive, highest for the Wadden Sea (0.86) and UK ( $) .76)$ but still good for all sampling locations for the Belgian nursery ground $(0.69+0 .:)$. Contributions to nursery discrimination varied among elements. Mean decre.a ${ }^{-\infty}$.n Gini index indicated that Mg, $\mathrm{Mn}$ and $\mathrm{Ba}$ were the three most important $\epsilon^{\prime} e m$ ents for classification accuracy, achieving an accuracy of $57 \%$ using just thrna ihree elements (Fig. 3). Otolith edges, representing the chemical signatures of $\iota_{1}$. sampling locations, were significantly different in $\mathrm{Na}(\mathrm{KW}=60.87,13, p<0$ su $)$, Mg (131.24, 6, $p<0.001)$, Mn (95.77, 6, $p$

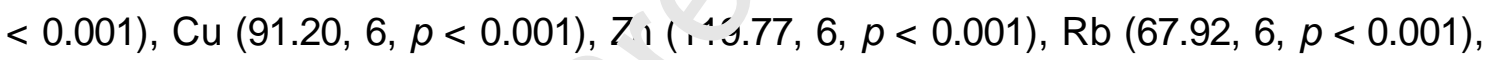
$\mathrm{Sr}$ (66.587, 6, $p<0.001)$, $\mathrm{Ba}$ (.13 J0, b, $p<0.001)$ and $\mathrm{Pb}(65.27,6, p<0.001) . \mathrm{Mg}$, $\mathrm{Mn}$ and $\mathrm{Ba}$ concentrations were s.jnificantly lower in UK samples, compared to the Wadden Sea and most Bolgicn sampling locations (exceptions were the low $\mathrm{Ba}$ concentrations in B2 and E3). The Wadden Sea was characterized by the highest average concentration $a$. $d d$ the highest variability in Mn concentrations compared to the other nursery grounds, ind high Ba concentrations (similar to B1 and B4). The Belgian nursery ground wa $\mathrm{c}^{\text {l}}$ aracterized by the highest $\mathrm{Mg}$ and $\mathrm{Pb}$ concentrations, and $\mathrm{Mn}$ levels in bet:'e€? Ul. and the Wadden Sea (Fig. 4).

Incorrec 1 assignments were low for the UK and the Wadden Sea nursery grounds (<26\%; Table 3). However, Belgian sampling locations were often confounded with each other with re-assignment errors of 0.6 to $32.4 \%$ (Table 3). These errors were due to similarities in otolith concentrations for $\mathrm{Mn}$ (B1-B2-B3-B4), Rb (B1-B2-B3), Pb (B1-B2-B4), Mg, Cu, and Sr (B2-B3-B4) or Na, and Ba (B1-B4 and B2-B3, Fig. 4). Assignment errors were highest for the sole from B4 (32.4\% in B1) and B2 (26.0\%). Assignment errors to another region were also common for sole juveniles captured on the Belgian nursery ground. For example $14.3 \%$ of B3 juveniles were assigned to the UK nursery ground and $26.8 \%$ of those from B4 were assigned to the Wadden Sea nursery ground. UK and B3 were similar in $\mathrm{Na}, \mathrm{Cu}, \mathrm{Rb}, \mathrm{Ba}$ and $\mathrm{Pb}$ concentrations (Fig. 4, Table 3). The Wadden Sea and the Belgian nursery grounds had similar $\mathrm{Cu}, \mathrm{Sr}$, and Ba signatures. Only $14.9 \%$ of the juveniles captured on the UK nursery were assigned 
to the Belgian nursery ( $8.7 \%$ to B3 in particular) and $11.5 \%$ to the Wadden Sea nursery. Similarly, only $14.5 \%$ of the juveniles captured on the Wadden Sea nursery ground were assigned to the Belgian nursery (especially to B2 and B3).

\subsection{Temporal variation in elemental signatures at the sampling location}

Differences in otolith signatures among sampling lxcations might partly result from temporal variations in local environmental conditions $t$ ?th year and sampling region were significant (MANOVA, df $=4, \mathrm{~F}=28.54, p<0.0 \mathrm{~s} 1$ and $\mathrm{df}=2, \mathrm{~F}=18.86, p<$ 0.001 , respectively). Interestingly, some chemi al $f$ lements -like $\mathrm{Mn}$ and $\mathrm{Ba}-$ were more impacted by year of sampling than othor $t$ '?ments (Fig. 5). The first and second principal components together explained $5_{4} 1 \%$ of the variance. The first axis, which was mainly determined by $\mathrm{Mg}, \mathrm{Cu}$ anr $\mathrm{Ro}$ (in growing order of importance), and the second axis, which was mainly deter $n_{1}:-1$ by $\mathrm{Mn}, \mathrm{Ba}$ and $\mathrm{Sr}$, overlapped between the three sampling regions. The ' $v a r$ der, Sea was the most distinct nursery ground, characterized by high $\mathrm{Mn}$ and $\mathrm{Ba}_{\mathrm{a}}$, and low Sr and $\mathrm{Cu}$ concentrations, while UK was characterized by low $\mathrm{Mg}$ and hish Sr concentrations.

Interannual varia 10 , in otolith edge signatures were observed at both B3 and B6 sampling locations Dliiarences between 2013 and 2014 signatures were significant $(p<0.001)$ at both $\mathrm{lc}$ :ations for four elements $(\mathrm{Mg}, \mathrm{Mn}, \mathrm{Cu}$ and $\mathrm{Pb}$; $\mathrm{Mg}(207, p<$ 0.001), $\mathrm{Mn}$ (17r, $\mu<0.01)$, $\mathrm{Cu}(31.5, p<0.01)$, and $\mathrm{Pb}(38.5, p<0.01)$ for $\mathrm{B} 3$; $\mathrm{Mg}$ (253, $p<0.06$ :' Ivin (265.5, $p<0.001), \mathrm{Cu}(54, p<0.001)$, and $\mathrm{Pb}(272, p<0.001)$ for B6.) out of ni... Other elements were not significantly different between years: $\mathrm{Zn}$ (72.5, $p=0.176), \operatorname{Rb}(163.5, p=0.014), \operatorname{Sr}(154, p=0.040), \mathrm{Ba}(106, p=0.983)$ for B3; $\mathrm{Na}(\mathrm{W}=84, p=0.023), \mathrm{Rb}(129, p=0.438), \mathrm{Sr}(98, p=0.072)$ for B6. Additionally, significant interannual variations in $\mathrm{Na}$ signatures $(\mathrm{W}=192.5, p<0.001)$ were observed at $\mathrm{B} 3$, while the concentrations at $\mathrm{B} 6$ showed significant variations in $\mathrm{Zn}$ ( $\mathrm{W}=$ 306, $p<0.001)$ and $\mathrm{Ba}(\mathrm{W}=279.5, p<0.001)$.

\subsection{Prediction of movement after settlement}

Post-settlement signatures of most juveniles were assigned to a sampling location within the region of capture $(79.3 \%)$, or even to the capture location itself $(46.1 \%)$. The 
observation suggests that the movements of juvenile sole on the nursery ground are restricted after settlement (Table 4). However, post-settlement signatures of some fish were assigned to another region than the final capture location. For example, $54.0 \%$ of the juveniles captured on the UK nursery ground had post-settlement signatures assigned to the Belgian nursery ground (mostly to B3, Table 4). These assignments could be explained by similarities in $\mathrm{Na}, \mathrm{Cu}, \mathrm{Rb}, \mathrm{Sr}, \mathrm{Ba}$, and $\mathrm{Pb}$ concentrations on the Belgian and UK nursery grounds leading to error in classification accuracy (Table 3, Fig. 4). Similarly, $24.3 \%$ of the juveniles captured in the Wadden Sea were assigned post-settlement to the Belgian nursery. On the $\mathrm{c}^{\text {thar }}$ hand, a lower proportion of juveniles captured on the Belgian nursery ground wrie assigned to the UK coast $(14.7 \%)$ or to the Wadden Sea $(19.4 \%$, Table 4$)$. Thf post-settlement otolith signatures from the juveniles captured on the UK nurcarv yrounds and assigned to the Belgian nursery (especially B3) were high in Mg aı, '.ow in Ba and Pb (Fig. 6), similarly to those recorded in the otolith edges $v^{\prime}$ juveniles from B1. Similarly, some postsettlement signatures from juveniles sap.iried in the Wadden Sea nursery ground were assigned to the Belgian nurse $\mathrm{v} c$ cound (especially B2), due to the higher values for $\mathrm{Mg}, \mathrm{Mn}, \mathrm{Cu}$, and $\mathrm{Pb}$.

\subsection{Natal sources}

K-means clusteriny idf ntified four clusters of chemically distinct larval signatures (Fig. 7 ), suggesting $f$ ur 1 atal sources for the Southern North Sea nursery grounds. Sources 1 and 3 were the main contributors to the Belgian nursery ground; they were characterized by the highest concentrations in $\mathrm{Mn}$ and $\mathrm{Ba}$ for source 1, and low concentrations in $\mathrm{Mg}, \mathrm{Cu}$, and $\mathrm{Rb}$, and the lowest $\mathrm{Na}$ concentrations for source 3 (Fig. 7, Suppl. Fig. 2 and Suppl. Table 3b). Source 4 was characterized by the lowest Mn and $\mathrm{Ba}$ concentrations. Its contribution to the Belgian and the UK nursery grounds was overall lower but it represented the most abundant source of juveniles at two of the four Belgian sampling locations for some sampling years (B3 in 2014 and Zandvliet in 2007). The UK nursery grounds primarily received individuals from source 3 , while Wadden Sea received juveniles from all three other sources (1, 2 and 4). However, source 2 only supplied the Wadden Sea nursery ground, mostly Balgzand. 


\section{Discussion}

Spatial differences in otolith elemental chemistry discriminated juvenile sole on the UK and the Wadden Sea nursery grounds and indicated some overlap between both nursery grounds and the Belgian nursery ground. Post-settlement signatures were mostly assigned to the closest sampling location. This suggests limited movement of juvenile sole after settlement on the nursery grounds, provided there is little to no temporal variability in signatures between the time at settlement and the time at capture. The mixed contributions of four chemically cis +inct natal sources to the three focal regions in the Southern North Sea points towc $r d$ a l extensive connectivity during larval dispersal.

Strong chemical differentiation on the -'1rsery grounds and limited movement after settlement

Despite the challenge of workir sampling locations) and in ₹ coastal area with various terrestrial influences, the chemical signatures of eigh $t$ 凡 ments provided high nursery-specific assignment levels for the juvenile sole. As ily. 'ment rates to the nursery grounds within the same region (76.1\%) were compa: ible vith previous studies (Cuveliers et al. 2010: 88\%, Tanner et al. 2012: $71-80 \%$ ) Eig, + elements were selected by the optimal RF classifier to achieve the highest ac iurcy, but the first five elements were sufficient to achieve an assignment ac-Uracy of $70 \%$. Errors in assignment were low for the UK and the Wadden Sea ...ursery grounds (<26\%). In contrast, Belgian sampling locations were often confounded with each other due to similarities in otolith concentrations for several elements. Assignment errors to another region were also common for sole juveniles captured on the Belgian nursery ground. The UK and the Belgian nursery grounds were similar in $\mathrm{Na}, \mathrm{Cu}, \mathrm{Rb}, \mathrm{Ba}$ and $\mathrm{Pb}$ concentrations while the Wadden Sea and the Belgian nursery grounds had similar $\mathrm{Cu}, \mathrm{Sr}$, and $\mathrm{Ba}$ signatures. Freshwater sources entering the Southern North Sea are the estuaries of the Thames, Scheldt, Meuse, Rhine and Ems-Dollard rivers. The high assignment success we found might be attributed to the chemical composition of these rivers as each drains basins with a distinct geology: Mesozoic Alp geology for the Rhine, Eocene deposits of the Scheldt, Paleocene deposits for the Thames, and Quaternary deposits for the Ems and Dollard (Hartmann et al. 2014, Preusser 2008, Yang \& Nio 1989). 
In addition to geo-specific river signatures, other influences may be attributed to the pollution history and differences in fish ecophysiology (see below). The North Sea is one of the most polluted seas world-wide due to the high level of industrialization and urbanization (Grizzetti et al. 2017). Despite a decreasing trend in metal concentrations due to strict regulations since the 1980s (Emeis et al. 2015), local concentrations in sediment and suspended matter remain high (De Witte et al. 2016). In this study otolith Sr concentrations were lowest in the Wadden Sea and $\mathrm{Ba}$ concentrations highest in estuarine environments (i.e. Zandvliet, Balgzand anri the Ems-Dollard Estuary). The patterns of otolith Sr and Ba usually matched the colini,' gradients (Campana 1999, Leakey et al. 2009). Zandvliet is situated in the $h_{c_{c}}{ }^{k^{i}}$ sh part of the Scheldt Estuary where salinity reaches a value of about 6 (Le C. . et al. 2017). Similarly, Balgzand and the Ems-Dollard Estuary are low salinity nיe€.!' grounds. Additional sources of $\mathrm{Ba}$ include terrestrial runoff, groundwater, polı ${ }^{+i}, n$ and remobilization from sediments (Hamer et al. 2006). A recent $\mathrm{mr}, \mathrm{co}$ analysis showed that otolith $\mathrm{Sr}$ and $\mathrm{Ba}$ concentrations may be influenced sy ....rinsic factors such as diet, condition and ontogeny and additional extrins' ; fa ;tors such as the ecological niche (Izzo et al. 2018), supporting former evidence (Stur, ’ck et al. 2012). Balgzand and the Ems-Dollard Estuary exhibited similar cons,e, trations for most elements although they were located in different tidal basins of $\mathrm{t} \div$ ' Vadden Sea and were sampled eight years apart. For example, both locations exhıoited high Mn concentrations that may reflect enrichment of the Wadden Sea in u. ssolved and particulate Mn compared to the surrounding water masses and/or hvp $7 x i$; conditions (Limburg et al. 2015). Pb, $\mathrm{Cu}$ and $\mathrm{Zn}$, which are associated $:$ 'ith noll' tion, were higher in sole otoliths from the Belgian coast compared to the Thames i:stuary, while Rb levels, which are associated with ingested plastic pollution (Lavers \& Bond 2016), were similar. The eastern Belgian coast is influenced by the highly industrialized Scheldt Estuary, with continuing and past traces of heavy metal pollution (Zwolsman et al. 1996), whereas the inner Thames Estuary has been rehabilitated (Andrews \& Rickard 1980, Grizzetti et al. 2017). Despite the distance between the two UK sampling locations, the chemical similarities were supported by the northeast residual current (Grizzetti et al. 2017).

Similarity in chemical signatures between recently settled juveniles and juveniles captured later on in the same nursery ground points to limited movement after settlement. In this study random forest (RF) classification of the post-settlement signatures assigned $21 \%$ of the juveniles to another sampling region than that of their final capture. The value fits with the overall observation that juvenile flatfish remain 
localized (within 3-40 km) on the nursery grounds (Le Pape \& Cognez 2016). However, the post-settlement signatures depend on the local water characteristics which might change over time (Chang \& Geffen 2013). Most assignments of post-settlement signatures to another sampling region might be linked to the spatial accuracy of the optimal RF classifier. Indeed, juveniles that settled in the Belgian nursery might have moved after settlement to be captured off the Dutch coast (and vice versa). Instead, otolith microchemistry might be influenced by time and physiological processes (Chang \& Geffen 2013, Reis-Santos et al. 2012, Sturrock e' al. 2012). For example, high Sr levels are associated with high growth rates during mota norphosis (De Pontual et al. 2000). We therefore specifically looked at eleme, tc outside the nucleus and the metamorphosis zone (after the $\mathrm{Sr}$ peak) to गvo' measuring chemical variation associated with ontogeny. However, tempcral v riability in the microchemical signal might be driven by seasonal or interannua.' "sriation (Tanner et al. 2012). Although most studies found a significant effect i season or year on the microchemical signal, temporal variation did not hinder spatial «..ucrimination, just as confirmed in the present study (Cuveliers et al. 2010, Re s-s antos et al. 2012, Tanner et al. 2012).

The interannual variatı $n$ in chemical signature at two Belgian sampling stations was significant for several $c^{h} \in$ : iical elements and year had a significant effect overall when considering all $s \mathrm{~m}^{\prime}{ }^{\prime}$ ing regions and chemical elements. This suggests that temporal variation his iv be taken into account to use otolith signatures for geolocation. But it rour : also mean that different sources supply the nursery throughout the years. Bior nys cal models point at considerable interannual variation of larval connectivity, $w_{1}:-n$ correlates with interannual recruitment variability (Bolle et al. 2009, Lacroix et al. ¿u 13, 2018). Although recruitment variability has been attributed to winter mortality in adult sole (Rijnsdorp et al. 1992), overall variation in recruitment, which might be affected by hydrodynamics and life history traits, remains incompletely understood. It is a common thread in the knowledge on many fish stocks (Cury et al. 2014).

Identification of chemically distinct natal sources and larval dispersal

The identification of the natal sources contributing to each nursery ground is key for understanding the dynamics of the population structure. Here, the eight most reliable elements to discriminate juvenile sole grouped in four chemically distinct sources. Each 
nursery ground received individuals from three of the four chemically distinct natal sources, albeit in different proportions. Sources 1, 3 and 4 contributed to the UK and Belgian nursery grounds, while source 1,2 and 4 contributed to the Wadden Sea nursery ground. Hence, empirical observations on juvenile sole point in the direction of local recruitment supplemented with external input. This is exactly what a biophysical model of larval sole predicted: a mixed input from several spawning grounds to most North Sea nursery grounds (Lacroix et al. 2013). Interestingly, the model predicted that the UK nursery ground is mostly self-recruiting, s:milar to what we observe. The Wadden Sea was supplied uniquely and almost exr'.'sı ly at Balgzand by source 2. This phenomenon is observed in some of the modt'ar years by Lacroix et al. (2013). Important is that the absence of a source on 2 1.' Irs', ry ground might also be linked to interannual fluctuations in the contributions $\mathrm{s}^{\mathrm{f}}$ the various spawning grounds (Lacroix et al. 2013).

The spawning location is tight,' lin sed to the nursery grounds. The spawning grounds of North Sea sole are Ir vi 'ea nore inshore and in shallower waters compared to other flatfish (Rijnsdorp et al. 1992). Flatfish optimize settlement success in two ways. Firstly, successful spav'ning ground locations have been selected over time and flatfish have a high fidelity tr, Leir spawning ground (Hunter et al. 2003). One of the most important require neı.'s of a successful spawning ground is the presence of suitable hydrographic -onuitions to transport eggs and larvae to the nursery ground (Symonds \& Rogrrs 395). Secondly, settlement can be delayed up to three weeks (Marchand $199^{+}$for common sole). Factors triggering the delay are linked to terrestrial and benthic crı mical cues, and freshwater input (Dixson et al. 2011, Freckelton et al. 2017, Kerstan 1991). The absence of a source 3 signature in the northeast and the presence of some individuals with a source 3 signature on the UK and the Belgian nursery grounds might suggest that source 3 is linked to the English Channel spawning ground, as was predicted by modeling (Lacroix et al. 2013). In the English Channel and Southern North Sea a northeast residual current has been well described, although its intensity may vary among years (Sentchev et al. 2006). In addition, source 3 resembles the UK nursery signature as it is characterized by low $\mathrm{Mg}, \mathrm{Cu}$, and the lowest $\mathrm{Na}$ concentrations. Higher $\mathrm{Ba}$ concentrations in source 3 compared to the UK nursery ground suggest that the spawning ground linked to source 3 is located offshore. Source 1, characterized by high $\mathrm{Na}, \mathrm{Mg}, \mathrm{Mn}$, and $\mathrm{Ba}$ and low $\mathrm{Cu}$ concentrations, contributed a lot to the Belgian nursery but also to the Wadden Sea nursery. Source 1 could be located close to the Belgian coast as its signature resembles the signature of the 
Belgian nursery with high $\mathrm{Na}, \mathrm{Mg}, \mathrm{Mn}$, and also high Ba concentrations. Zandvliet and Balgzand, two locations under estuarine influence, were each supplied by a single natal source (source 4 and 2, respectively). The specific signatures of Zandvliet and Balgzand might be an artefact of the low sample size because the K-means clustering method used is sensitive to sample size and less likely to identify small larval clusters.

Several spawning grounds contribute to the sole nursery grounds in the Southern North Sea, according to our results. This is a validation of several model predictions (Barbut et al. 2019, Bolle et al. 2009, Luiroix et al. 2013, Savina et al. 2010). Biophysical individual-based models are c rgucbly one of the best tools to explore transport dynamics of flatfish larvae $\mathrm{Hu}$ ingl et al. 2013) as they allow predictions over a large spatial extent and a igh temporal frequency, far more than can be realized empirically. However, he ack of precise information on key parameters for larval survival such as swir.ıminy capability, mortality and pelagic larval duration hamper the parametrization ( $f$ bf havior routines of individual-based models. Although the biological paramet' $<$ tio. of these models includes many assumptions, the current parametrization seeı $\varsigma$ sufficient for a semi-quantitative assessments of dispersal. A next step wouli be to confirm the modelled variation between years. Interannual variation in hy rra, vamics and life history dynamics considerably impact recruitment (Gibson 205 ). Sonnectivity research based on microchemistry requires the establishment of $i$ exiensive chemical baseline from putative sources (i.e. larvae in the spawning grounc 2 and juveniles on the nursery grounds) to re-assign individuals of unknown ori „In (Gillanders et al. 2005). Establishing an extensive baseline is not always feasibı que to spatio-temporal sampling limitations and knowledge gaps. However, statisucal tools incorporating uncertainty and enabling assignment to missing sources provide an a useful supporting tool. For example, Bayesian models provide uncertainty of assignment estimates (Reis-Santos et al. 2018). Estimating the potential number of sources would help to proceed during the validation step (i.e. know better how many spawning sources to sample) and allow hypothesis-testing of the contribution of different spawning grounds to focal nursery grounds using other methods such as genetic markers (Reis-Santos et al. 2018). Nevertheless, using Bayesian models does not eliminate the need to validate the contribution of each spawning ground to the nursery grounds. Determining the chemical signal of larvae on the spawning grounds is key to validating connectivity patterns. 
Important larval dispersal supports the observation that the population genetic structure of sole in the North Sea is homogeneous (Cuveliers et al. 2012, Diopere et al. 2018) and could come from a high level of gene flow. However, larvae move less than might be expected from advection. For example, plaice larvae are retained on the spawning grounds due to nycthemeral migration (Fox et al. 2009) and selective tidal transport (Rijnsdorp et al. 1985). Hence, despite the homogenous genetic structure, some structure is present with fish adapted to the local environment (Diopere et al. 2018). Limited differences in natal sources were or served between the UK and the Belgian nursery grounds, compared to the Wadden $C$ a. Differences in natal sources were also present within the Wadden Sea nursery ar sund. So, the main drivers of otolith chemistry are operating at a local scale 11 эpr oximately $100 \mathrm{~km}$, or even less in the case of the Wadden Sea, as supported hv assignment. This finding is consistent with an average dispersal distance of sole ${ }^{+}+$ioout $150 \mathrm{~km}$ based on tagging studies (Burt \& Millner 2008), biophysical mor'ci. (Barbut et al. 2019) and genetic markers (Diopere et al. 2018, Kotoulas et al. 2995). Field surveys reported comparable dispersal distances between s' aw ing and nursery grounds $(80-100 \mathrm{~km}$, Dorel et al. 1991). Although local settlement is : common feature of many marine species (Pinsky et al. 2017) sole has a goor aı - nersal potential. Interestingly, dispersal potential might be linked to spawning date. For example, summer spawning flatfish, such as sole, turbot and brill, dispers. less further than winter spawning flatfish such as common dab, European floun ${ }^{\mathrm{N}}$ er and European plaice (Barbut et al. 2019).

The shi' $\mathrm{Ir}$, location of the spawning and nursery grounds, and spawning season may $\mathrm{k}$ ग to important changes in connectivity. Global change has been affecting fish aııd plankton communities in the North East Atlantic Ocean over the last 20 years such that the ranges of many species have shifted northward (Beaugrand et al. 2002, McLean et al. 2018). The spawning season of sole has shifted to earlier in the year (Fincham et al. 2013) but the distribution of adults has shifted southward. The most likely reason is that sole have shifted to deeper waters (Engelhard et al. 2011). Although spawning and nursery ground locations have not shifted yet, modeling predicts geographical shifts in connectivity and larval recruitment at the nursery grounds due to climate change (Teal et al. 2012, Lacroix et al. 2018). 
This study provides new evidence on the early-life connectivity of sole, during the stages when most of the realized dispersal is assumed to take place in the species (Batista et al. 2015, Krueck et al. 2017). The connectivity of sole is extensive at the larval stage and limited at the juvenile stage. The high spatial discrimination of the microchemical signal of sole otoliths identified several natal sources and connectivity patterns in the southern North Sea. The new evidence on the local connectivity dynamics of the early-life stage of sole is consistent with the output of several biophysical models of larval dispersal (Barbut et al. 2019, Bolle et al. 2009, Lacroix et al. 2013). This confirms that elemental analysis is a valuable tool for species with extended larval dispersal and low genetic cifforentiation. Understanding the directionality of flow between larval sources (i.. s sawning grounds) and sinks (i.e. nursery grounds), and connectivity pattern = is crucial for the management of the intensively fished stocks (ICES 2018) and $t_{1}$, , roper design and functioning of Marine Protected Areas (Botsford et al. 2001, «c ines et al. 2010). Several questions related to the population dynamics and ecolor.y u. sole remain to be addressed. For example what is the contribution of ir err nnual variation to dispersal, what is the role of (sub)adult dispersal, what is the ay--specific mortality rate, and what is the contribution of phenotypic plasticity and colt:-ition to local environmental pressures.

\section{Acknowledgements}

Special tharks o K Vanhalst (Institute for Agricultural and Fisheries Research, ILVO), the crew of RV Iimon Stevin, RV Stern, RV Cefas Endeavour and RV Belgica, L. Bolle (Wageningen Marine Research, NL), J. Smith (Cefas, UK) and the B-FishConnect team for sampling, and to two anonymous reviewers for insightful comments. Research was funded by the B-FishConnect research project $(\mathrm{G} .0702 .13 \mathrm{~N})$ and the Scientific Research Network 'Eco-evolutionary dynamics in natural and anthropogenic communities' (grant W0.037.10N), both funded by the Research Foundation - Flanders (Belgium). 


\section{References}

Allouche, O., Tsoar, A., Kadmon, R., 2006. Assessing the accuracy of species distribution models: prevalence, kappa and the true skill statistic (TSS). Journal of Applied Ecology 43, 1223-1232. https://doi.org/10.1111/j.1365-2664.2006.01214.x

Amara, R., Meziane, T., Gilliers, C., Hermel, G., Laffargue, P., 2007. Growth and condition indices in juvenile sole Solea solea measured to assess the quality of essential fish habitat. Marine Ecology Prooress Series 351, 201-208. https://doi.org/10.3354/meps07154

Amara, R., Poulard, J.-C., Lagardère, F., Désauna; '.,, 1998. Comparison between the life cycles of two Soleidae, the common sc! $\epsilon$, Sr lea solea, and the thickback sole, Microchirus variegatus, in the Bay of Biscav' 53, 193-209. https://doi.org/10.1023/A:10074,?=204955

Andrews, M.J., Rickard, D.G., 1980. R th th litation of the inner Thames estuary. Marine Pollution Bulletin 11, 327-332. h+rac, roi.org/10.1016/0025-326X(80)90051-X

Anstead, K.A., Schaffler, J.J., v.nes, C.M., 2015. Coastwide otolith signatures of juvenile Atlantic menhaden, 2009-2011. Transactions of the American Fisheries Society 144, 96-106. https //r.0 .urg/10.1080/00028487.2014.969407

Barbut, L., Groot Creg, C., Delerue-Ricard, S., Vandamme, S., Volckaert, F.A.M., Lacroix, G., 2019. Hov: the larval traits of six flatfish species impact connectivity. Limnology and Oce inr graphy 64, 1150-1171. https://doi.org/10.1002//no.11104

Batista, M.I., 'H.... ques, S., Pais, M.P., Cabral, H.N., 2015. A framework for the assessment $c^{f}$ 'MPA effectiveness based on life history of fishes. Ocean \& Coastal Management, Coastal systems under change 118, Part A, 75-87. https://doi.org/10.1016/j.ocecoaman.2015.11.010

Beaugrand, G., Reid, P.C., Ibañez, F., Lindley, J.A., Edwards, M., 2002. Reorganization of North Atlantic marine copepod biodiversity and climate. Science 296, 1692-1694. https://doi.org/10.1126/science.1071329

Bolle, L.J., Dickey-Collas, M., Beek, J.K.L. van, Erftemeijer, P.L.A., Witte, J.I., Veer, H.W. van der, Rijnsdorp, A.D., 2009. Variability in transport of fish eggs and larvae. III. Effects of hydrodynamics and larval behaviour on recruitment in plaice. Marine Ecology Progress Series 390, 195-211. https://doi.org/10.3354/meps08177 
Botsford, L.W. Hastings, A., Gaines, S.D., 2001. Dependence of sustainability on the configuration of marine reserves and larval dispersal distance. Ecology Letters 4, 144150. https://doi.org/10.1046/j.1461-0248.2001.00208.x

Breiman, L., 2001. Random forests. Machine Learning 45, 5-32. https://doi.org/10.1023/A:1010933404324

Brophy, D., Danilowicz, B.S., Jeffries, T.E., 2003. The detection of elements in larval otoliths from Atlantic herring using laser ablation ICP-MS. Journal of Fish Biology 63, 990-1007. https://doi.org/10.1046/j.1095-8649.2003.00_?3.x

Burt, G.J., Millner, R.S., 2008. Movements of solt in the southern North Sea and eastern English Channel from tagging studies (; 955 -2004). Science Series Technical Report. Cefas Lowestoft, 143 : 1-44

Campana, S.E., 1999. Chemistry and cu. nposition of fish otoliths: Pathways, mechanisms and applications. Marine ':c slingy Progress Series 188, 263-297.

Chang, M.-Y., Geffen, A.J., 201?. Taxinomic and geographic influences on fish otolith microchemistry. Fish and Fis. - aries 14, 458-492. https://doi.org/10.1111/j.14672979.2012.00482.x

Charrad, M., Ghazzali, N., F oi eau, V., Niknafs, A., 2014. NbClust: An R package for determining the releva't number of clusters in a data set. Journal of Statistical Software 61, 1-36. $\mathrm{rttp}: / /$ doi.org/10.18637/jss.v061.i06

Cowen, R., Gav^rkı:vicz, G., Pineda, J., Thorrold, S., Werner, F., 2007. Population connectivity in r.arine systems: An Overview. Oceanography 20, 14-21. https://doi.org/10 j670/oceanog.2007.26

Cury, P.M., J.-M. Fromentin, S. Figuet, Bonhommeau, S. 2014. Resolving Hjort's dilemma: How is recruitment related to spawning stock biomass in marine fish? Oceanography 27, 42-47, http://dx.doi.org/10.5670/oceanog.2014.85

Cuveliers, E.L., Geffen, A., Guelinckx, J., Raeymaekers, J. A. M., Skadal, J., Volckaert, F.A.M., Maes, G.E., 2010. Microchemical variation in juvenile Solea solea otoliths as a powerful tool for studying connectivity in the North Sea. Marine Ecology Progress Series 401, 211-220. https://doi.org/10.3354/meps08439

Cuveliers, E.L., Larmuseau, M.H.D., Hellemans, B., Verherstraeten, S.L.N.A., Volckaert, F.A.M., Maes, G.E., 2012. Multi-marker estimate of genetic connectivity of 
sole (Solea solea) in the North-East Atlantic Ocean. Marine Biology 159, 1239-1253. https://doi.org/10.1007/s00227-012-1905-x

Darnaude, A., Hunter, E., 2018. Validation of otolith $\delta 180$ values as effective natural tags fors shelf-scale geolocation of migrating fish. Marine Ecology Progress Series 598, 167-185. https://doi.org/10.3354/meps 12302

De Witte, B., Ruttens, A., Ampe, B., Waegeneers, N., Gauquie, J., Devriese, L., Cooreman, K., Parmentier, K., 2016. Chemical analyses of dredged spoil disposal sites at the Belgian part of the North Sea. C'romosphere 156, 172-180. https://doi.org/10.1016/j.chemosphere.2016.04.124

Di Franco, A., Gillanders, B.M., Benedetto, G L P snnetta, A., Leo, G.A.D., Guidetti, P., 2012. Dispersal patterns of coastal fish. 1..plications for designing networks of

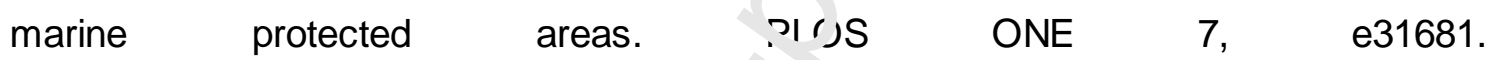
https://doi.org/10.1371/journal.pone.003.こ31

Diopere, E., Vandamme, S.G., Hahlı̈’el, P.I., Cariani, A., Van Houdt, J., Rijnsdorp, A., Tinti, F., Volckaert, F.A.M., Mac - i.E., 2018. Seascape genetics of a flatfish reveals local selection under high '?vels or gene flow. ICES Journal of Marine Science 75,

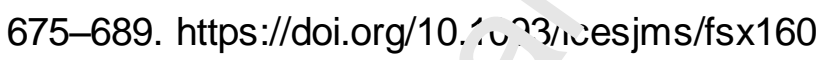

Dixson, D.L., Jones, G.P., Munday, P.L., Pratchett, M.S., Srinivasan, M., Planes, S., Thorrold, S.R., 2011. Ter,estrial chemical cues help coral reef fish larvae locate settlement habitat s.:rrounding islands. Ecology and Evolution 1, 586-595. https://doi.org/1'/.1し ר/ece3.53

Dorel, D., Koutsi opoulos, C., Desaunay, Y., Marchand, J., 1991. Seasonal distribution of young sole (Solea solea (L.)) in the nursery ground of the bay of Vilaine (Northern bay of Biscay). Netherlands Journal of Sea Research 27, 297-306. https://doi.org/10.1016/0077-7579(91)90032-V

Ellis, J.R., Milligan, S.P., Readdy, L., Taylor, N., Brown, M.J., 2012. Spawning and nursery grounds of selected fish species in UK waters. Science Series Technical Report, Cefas Lowestoft, 147.

Emeis, K.-C., van Beusekom, J., Callies, U., Ebinghaus, R., Kannen, A., Kraus, G., Kröncke, I., Lenhart, H., Lorkowski, I., Matthias, V., Möllmann, C., Pätsch, J., Scharfe, M., Thomas, H., Weisse, R., Zorita, E., 2015. The North Sea - A shelf sea in the Anthropocene. Journal of Marine Systems, Biogeochemistry-ecosystem interaction on 
changing continental margins in the Anthropocene 141, 18-33. https://doi.org/10.1016/j.jmarsys.2014.03.012

Engelhard, G.H., Pinnegar, J.K., Kell, L.T., Rijnsdorp, A.D., 2011. Nine decades of North Sea sole and plaice distribution. ICES Journal of Marine Science 68, 1090-1104. https://doi.org/10.1093/icesjms/fsr031

Fincham, J.I., Rijnsdorp, A.D., Engelhard, G.H., 2013. Shifts in the timing of spawning in sole linked to warming sea temperatures. Journal of Sea Research 75, 69-76. https://doi.org/10.1016/j.seares.2012.07.004

Fox, C.J., McCloghrie, P., Nash, R.D.M., 2009. Pot nti•.l transport of plaice eggs and larvae between two apparently self-contained $p$ ' vul tions in the Irish Sea. Estuarine, Coastal and Shelf Science 81, 381-389. httpr//civi.org/10.1016/j.ecss.2008.10.024

Freckelton, M.L., Nedved, B.T., Hadfield, M.C 2017. Induction of invertebrate larval settlement; different bacteria, differe' it ,r echanisms? Scientific Reports 7, 42557. https://doi.org/10.1038/srep42557

Gaines, S.D., Lester, S.E., Groru -Colvert, K., Costello, C., Pollnac, R., 2010. Evolving science of marine reserves. New developments and emerging research frontiers. Proceedings of the $\mid \mathrm{la}^{\dagger} \mathrm{c} \sim \mathrm{al}$ Academy of Sciences 107, 18251-18255. https://doi.org/10.1073/p ras. 1 U02098107

Gibb, F.M., Régnier I., Donald, K., Wright, P.J., 2017. Connectivity in the early life history of sandeel infer red from otolith microchemistry. Journal of Sea Research 119, 8-16. https://do. org 10.1016/j.seares.2016.10.003

Gibson, R.N., 2 J15. Behaviour and the distribution of flatfishes. Journal of Sea Research 37, 241-256.

Gillanders, B.M., 2005. Using elemental chemistry of fish otoliths to determine connectivity between estuarine and coastal habitats. Estuarine, Coastal and Shelf Science 64, 47-57. https://doi.org/10.1016/j.ecss.2005.02.005

Gillanders, B.M., Kingsford, M.J., 2003. Spatial variation in elemental composition of otoliths of three species of fish (family Sparidae). Estuarine, Coastal and Shelf Science 57, 1049-1064. https://doi.org/10.1016/S0272-7714(03)00009-X

Grizzetti, B., Pistocchi, A., Liquete, C., Udias, A., Bouraoui, F., van de Bund, W., 2017. Human pressures and ecological status of European rivers. Scientific Reports 7, 1-11. https://doi.org/10.1038/s41598-017-00324-3 
Hamer, P.A., Jenkins, G.P., Coutin, P., 2006. Barium variation in Pagrus auratus (Sparidae) otoliths: A potential indicator of migration between an embayment and ocean waters in south-eastern Australia. Estuarine, Coastal and Shelf Science, Ecological and Management Implications on Seagrass Landscapes 68, 686-702. https://doi.org/10.1016/j.ecss.2006.03.017

Harden-Jones, F.R., 1968. Fish migration. New York : St. Martin's Press. 325 pp. Hartmann, J., Lauerwald, R., Moosdorf, N., 2014. A brief overview of the GLObal Rlver Chemistry Database, GLORICH. Procedia Earth and ?'anetary Science, Geochemistry of the Earth's surface GES-10 Paris France, 18-?3 August, 2014. 10, 23-27. https://doi.org/10.1016/j.proeps.2014.08.005

Hufnagl, M., Peck, M.A., Nash, R.D.M., Pohlmı nn, Г., Rijnsdorp, A.D., 2013. Changes in potential North Sea spawning grounds of Jlaic e (Pleuronectes platessa L.) based on early life stage connectivity to nursery ha'jitats. Journal of Sea Research 84, 26-39. https://doi.org/10.1016/j.seares.2012.1 ( $r, 0$;

Hunter, E., Metcalfe, J.D., Rev.lols s, J.D., 2003. Migration route and spawning area fidelity by North Sea plaice. Proct dings of the Royal Society B: Biological Sciences 270, 2097-2103. https://doi.nrg/ ^n.1098/rspb.2003.2473

Izzo, C., Reis-Santos, P, Giki-_.nders, B.M., 2018. Otolith chemistry does not just reflect environmental conditic ns. 4 meta-analytic evaluation. Fish and Fisheries 19, 441-454. https://doi.org/10.111: /faı.12264

Kerstan, M., 10 11 . The importance of rivers as nursery grounds for 0 - and 1-group flounder (Platı.'thys flesus L.) in comparison to the Wadden Sea. Netherlands Journal of Sea Researuı, Proceedings of the First International Symposium on Flatfish Ecology 27, 353-366. https://doi.org/10.1016/0077-7579(91)90038-3

Kotoulas, G., Bonhomme, F., Borsa, P., 1995. Genetic structure of the common sole Solea vulgaris at different geographic scales. Marine Biology 122, 361-375. https://doi.org/10.1007/BF00350869

Krueck, N.C., Ahmadia, G.N., Green, A., Jones, G.P., Possingham, H.P., Riginos, C., Treml, E.A., Mumby, P.J., 2017. Incorporating larval dispersal into MPA design for both conservation and fisheries. Ecological Applications 27, 925-941. https://doi.org/10.1002/eap.1495 
Lacroix, G., Barbut, L., Volckaert, F.A.M., 2018. Complex effect of projected sea temperature and wind change on flatfish dispersal. Global Change Biology 24, 85-100. https://doi.org/10.1111/gcb.13915

Lacroix, G., Maes, G.E., Bolle, L.J., Volckaert, F.A.M., 2013. Modelling dispersal dynamics of the early life stages of a marine flatfish (Solea solea L.). Journal of Sea Research 84, 13-25. https://doi.org/10.1016/j.seares.2012.07.010

Lagardère, F., Chaumillon, G., Amara, R., Heineman, G., Lago, J.M., 1995. Examination of otolith morphology and microstructure us ing laser scanning microscopy. Recent Developments in Fish Otolith Research. 3elle W. Baruch Library in Marine Science, University of South Carolina, Hilton Hea 1 1s 7-27.

Lagardère, F., Troadec, H., 1997. Age estimatic.? in common sole Solea solea larvae: Validation of daily increments and evaluatior, of $A$ pattern recognition technique. Marine Ecology Progress Series 155, 223-237 i, tos://doi.org/10.3354/meps 155223

Lavers, J.L., Bond, A.L., 2016. Innes 'ad plastic as a route for trace metals in Laysan albatross (Phoebastria immutu hili,) and Bonin petrel (Pterodroma hypoleuca) from Midway Atoll. Má-ine Pollution Bulletin 110, 493-500. https://doi.org/10.1016/j.mar $\mu$ 'bui.2016.06.001

Le Coz, M., Chambord. S., Vieire, P., Maris, T., Azémar, F., Ovaert, J., Buffan-Dubau, E., Kromkamp, J.C., 'ossuu, A.C., Prygiel, J., Spronk, G., Lamothe, S., Ouddane, B., Rabodonirina, S., Net, S., Dumoulin, D., Peene, J., Souissi, S., Tackx, M., 2017. Test of some ecolo' ICái concepts on the longitudinal distribution of zooplankton along a lowland water ?ourse. Hydrobiologia 802, 175-198. https://doi.org/10.1007/s10750017-3256-6

Le Pape, O., Cognez, N., 2016. The range of juvenile movements of estuarine and coastal nursery dependent flatfishes: Estimation from a meta-analytical approach. Journal of Sea Research, 107, 43-55. https://doi.org/10.1016/j.seares.2015.06.001

Leakey, C.D.B., Attrill, M.J., Fitzsimons, M.F., 2009. Multi-element otolith chemistry of juvenile sole (Solea solea), whiting (Merlangius merlangus) and European seabass (Dicentrarchus labrax) in the Thames Estuary and adjacent coastal regions. Journal of Sea Research 61, 268-274. https://doi.org/10.1016/j.seares.2008.12.002

Limburg, K., 1995. Otolith strontium traces environmental history of subyearling American shad Alosa sapidissima. Marine Ecology Progress Series 119, 25-35. https://doi.org/10.3354/meps 119025 
Limburg, K.E., Walther, B.D., Lu, Z, Jackman, G., Mohan, J., Walther, Y., Nissling, A., Weber, P.K., Schmitt, A.K., 2015. In search of the dead zone: Use of otoliths for tracking fish exposure to hypoxia. Journal of Marine Systems, Biogeochemistryecosystem interaction on changing continental margins in the Anthropocene 141, 167178. https://doi.org/10.1016/j.jmarsys.2014.02.014

Marchand, J., 1991. The influence of environmental conditions on settlement, distribution and growth of 0-group sole (Solea solea (L.)) in a macrotidal estuary (Vilaine, France). Netherlands Journal of $S_{1}$ a Research 27, 307-316. https://doi.org/10.1016/0077-7579(91)90033-W

McLean, M.J., Mouillot, D., Goascoz, N., Sch aicr. I., Auber, A., 2019. Functional reorganization of marine fish nurseries under $\iota$ :mate warming. Global Change Biology 25, 660-674. https://doi.org/10.1111/gcb.14'01

Mercier, L., Darnaude, A.M., Bruguier, ר., Vasconcelos, R.P., Cabral, H.N., Costa, M.J., Lara, M., Jones, D.L., Mouillot, ( )., 2 2 11 . Selecting statistical models and variable combinations for optimal clrssit catıun using otolith microchemistry. Ecological Applications 21, 1352-1364. https:ı','roi.org/10.1890/09-1887.1

Mérigot, B., Letourneur, ‘., Ltcomte-Finiger, R., 2007. Characterization of local populations of the cor.: mL - sole Solea solea (Pisces, Soleidae) in the NW Mediterranean througr oilith morphometrics and shape analysis. Marine Biology 151, 997-1008. https://doı. rrg/10.1007/s00227-006-0549-0

Mille, T., Mahé, K., Villanueva, M.C., De Pontual, H., Ernande, B., 2015. Sagittal otolith morphogenesıs 7symmetry in marine fishes. Journal of Fish Biology 87: 646-663.

OSPAR commission, 2013. An assessment of the ecological coherence of the OSPAR Network of Marine Protected Areas in 2012.

Panfili, J., De Pontual, H., Troadec, H., Wright, P.J., 2002. Manual of fish sclerochronology. IFREMER-IR. ed. 463 pp. ISBN 2-7099-1490-5.

Paton, C., Hellstrom, J., Paul, B., Woodhead, J., Hergt, J., 2011. lolite: Freeware for the visualisation and processing of mass spectrometric data. Journal of Analytical Atomic Spectrometry. 26, 2508-2518. https://doi.org/10.1039/C1JA10172B

Pineda, J., Hare, J., Sponaugle, S., 2007. Larval transport and dispersal in the coastal ocean and consequences for population connectivity. Oceanography 20, 22-39. https://doi.org/10.5670/oceanog.2007.27 
Pinsky, M.L., Saenz-Agudelo, P., Salles, O.C., Almany, G.R., Bode, M., Berumen, M.L., Andréfouët, S., Thorrold, S.R., Jones, G.P., Planes, S., 2017. Marine dispersal scales are congruent over evolutionary and ecological time. Current Biology 27, 149154. https://doi.org/10.1016/j.cub.2016.10.053

De Pontual, H., Lagardere, F., Troadec, H., Batel, A., Desaunay, Y., Koutsikopoulos, C., 2000. Otoliths imprinting of sole (Solea solea) from the Bay of Biscay: A tool to discriminate individuals from nursery origins? Oceanologica acta 23, 497-513. 10.1016/S1385-1101(03)00080-7

Preusser, F., 2008. Characterisation and evolu on of the River Rhine system. Netherlands Journal of Geosciences - (ieor gie en Mijnbouw 87, 7-19. https://doi.org/10.1017/S0016774600024008

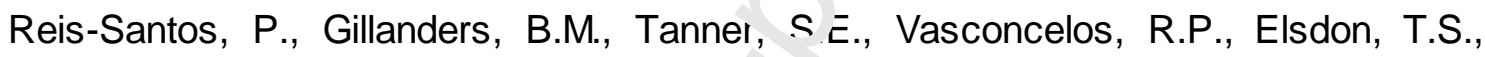
Cabral, H.N., 2012. Temporal variabilit iv estuarine fish otolith elemental fingerprints: Implications for connectivity asses:munis. Estuarine, Coastal and Shelf Science, Assessing Ecological Quality in Estuarine and Coastal Systems - Functional Perspective 112, 216-224. https://i i.org/10.1016/j.ecss.2012.07.027

Reis-Santos, P., Tanner, S.L Rijoim, M.A., Vasconcelos, R.P., Laroche, J., Charrier, G., Pérez, M., Presa, P, Gili_..ıders, B.M., Cabral, H.N., 2018. Reconciling differences in natural tags to infer de ’ographic and genetic connectivity in marine fish populations. Scientific Reports 8, iา343. https://doi.org/10.1038/s41598-018-28701-6

Rijnsdorp, A.D. Siı llen, M.V., Veer, H.W.V.D., 1985 Selective tidal transport of North Sea plaice larve Pleuronectes platessa in coastal nursery areas. Transactions of the American Fishtı les Society 114, 461-470. https://doi.org/10.1577/1548-8659

Rijnsdorp, A.D., Van Beek, F.A., Flatman, S., Millner, R.M., Riley, J.D., Giret, M., De Clerck, R., 1992. Recruitment of sole stocks, Solea solea (L.), in the Northeast Atlantic. Netherlands Journal of Sea Research 29, 173-192. https://doi.org/10.1016/00777579(92)90018-A

Russell, F.S., 1976. The Eggs and Planktonic Stages of British Marine Fishes. The Quarterly Review of Biology 52, 216-216. https://doi.org/10.1086/409937

Ruttenberg, B.I., Hamilton, S.L., Hickford, M.J.H., Paradis, G.L., Sheehy, M.S., Standish, J.D., Ben-Tzvi, O., Warner, R.R., 2005. Elevated levels of trace elements in cores of otoliths and their potential for use as natural tags. Marine Ecology-Progress Series 297, 273-281. 
Savina, M., Lacroix, G., Ruddick, K., 2010. Modelling the transport of common sole larvae in the Southern North Sea: Influence of hydrodynamics and larval vertical movements. Journal of Marine Systems 81, 86-98. https://doi.org/10.1016/j.jmarsys.2009.12.008

Shima, J.S., Swearer, S.E., 2010. The legacy of dispersal: Larval experience shapes persistence later in the life of a reef fish. Journal of Animal Ecology. 79, 1308-1314. https://doi.org/10.1111/j.1365-2656.2010.01733.x

Sentchev, A., Yaremchuk, M., Lyard, F., 2006. Revi'tual circulation in the English Channel as a dynamically consistent synthesis of shc e-based observations of sea level and currents. Continental Shef Research 26, 1884-1904. https://doi.org/10.1016/j.csr.2006.06.006

Sturrock, A.M., Trueman, C.N., Darnauh A.M., Hunter, E., 2012. Can otolith elemental chemistry retrospectively tra in migrations in fully marine fishes? Journal of Fish Biology 81, 766-795. https://doi. Jry'1'.J.1111/j.1095-8649.2012.03372.x

Symonds, D.J., Rogers, S.I., 1.95 The influence of spawning and nursery grounds on the distribution of sole Sole: solea (L.) in the Irish Sea, Bristol Channel and adjacent areas. Journal of Experimer.ıc' Niurine Biology and Ecology 190, 243-261.

Tanner, S., Reis-Santo;, ?, Vasconcelos, R., França, S., Thorrold, S., Cabral, H., 2012. Otolith geoche nistıy discriminates among estuarine nursery areas of Solea solea and S. seneqalt 'sis over time. Marine Ecology Progress Series 452, 193-203. https://doi.org/1',30 T4/meps09621

Tournois, J., Dá naude, A.M., Ferraton, F., Aliaume, C., Mercier, L., McKenzie, D.J., 2017. Lagoon nurseries make a major contribution to adult populations of a highly prized coastal fish. Limnology and Oceanography 62, 1219-1233. https://doi.org/10.1002/Ino.10496

Van der Land, M.A., 1991. Distribution of flatfish eggs in the 1989 egg surveys in the southeastern North Sea, and mortality of plaice and sole eggs. Netherlands Journal of Sea Research 27, 277-286. https://doi.org/10.1016/0077-7579(91)90030-5

Yang, C.-S., Nio, S.-D., 1989. An ebb-tide delta depositional model-a comparison between the modern Eastern Scheldt tidal basin (southwest Netherlands) and the Lower Eocene Roda Sandstone in the southern Pyrenees (Spain). Sedimentary Geology 64, 175-196. https://doi.org/10.1016/0037-0738(89)90091-2 
Zwolsman, J.J.G., van Eck, G.T.M., Burger, G., 1996. Spatial and temporal distribution of trace metals in sediments from the Scheldt Estuary, South-west Netherlands. Estuarine, Coastal and Shelf Science 43, 55-79. https://doi.org/10.1006/ecss.1996.0057 


\section{Figures and tables}

Figure 1: Map of the Southern North Sea showing the sampling locations for juvenile sole $(n=$ 213) off the British (UK), Belgian (BE) and Dutch Wadden Sea (WA) coasts. Codes for sampling locations include the station name (e.g. "B02" for "B02j13"), the life stage of the fish ("j" for juvenile) and the year of sampling ("13" for 2013). See also Table 1.

Figure 2: Transversal section of an otolith of juvenile sole (: ansmitted light, $x 80$ magnification) showing the laser ablation transect and selections $r \_p r$ senting the larval (core), postsettlement and nursery ground (edge) signatures rep esc ntıng the chemical fingerprints of the habitats occupied at each life history stage.

Figure 3: Effect of the number of ele nf n's included in the otolith signatures on the discrimination accuracy among the cave, sampling locations based on the Random Forest (RF) approach. The gray area shows the ir cerval between the minimum and maximum accuracies for each signature, while the $m_{\llcorner}$эn accuracy $( \pm S D)$ is depicted by the squares. The table shows the list of elements include $\mathrm{i}^{\prime}, 1$, ha optimal RF classifier ranked by the corresponding mean decrease in the Gini inde) (ir. nortance for spatial discrimination).

Figure 4: Box plc's f tı elemental composition (expressed as ratios to $\mathrm{Ca}$ ) of juvenile sole otoliths at all su nuiing locations (see Table 1). For each sampling location, the solid line and the box correspu. id to the median and the interquartile range, respectively. Different letters indicate groups of significantly different signatures based on Dunn's post hoc test $(p<0.05)$. The concentration of each element was normalized to ${ }^{43} \mathrm{Ca}$ (the internal standard) and expressed in $\mathrm{mol} \mathrm{mol}^{-1}$, except for $\mathrm{Na} / \mathrm{Ca}$ and $\mathrm{Sr} / \mathrm{Ca}$ (in mmol mol ${ }^{-1}$ ) and $\mathrm{Pb} / \mathrm{Ca}$ (in pmol mol ${ }^{-1}$ ).

Figure 5: Correlation biplot based on principal component analysis (PCA) of the elemental profiles of the otoliths of 213 juvenile sole. The position of the elemental vectors is indicated with respect to the first two principal components (PC1, PC2), which together explain $55 \%$ of the variance. The individual elemental profiles are organized by sampling region (UK, Belgian and Wadden Sea nursery). 
Figure 6: Elemental composition (expressed as ratios to $\mathrm{Ca}$ ) of juvenile sole otoliths in the transect selections representing settlement (dark grey) and sampling locations (light grey, see Table 1). For each sampling location, the solid line and the box correspond to the median and the interquartile range, respectively. Different letters indicate groups with significantly different signatures based on Dunn's post hoc test $(p<0.05)$. The concentration of each element was normalized to ${ }^{43} \mathrm{Ca}$ (the internal standard) and expressed in $\mu \mathrm{mol} \mathrm{mol}^{-1}$, except for $\mathrm{Na} / \mathrm{Ca}$ and $\mathrm{Sr} / \mathrm{Ca}$ (in $\mathrm{mmol} \mathrm{mol}^{-1}$ ) and $\mathrm{Pb} / \mathrm{Ca}$ (in pmol $\mathrm{mo}^{-1}{ }^{-1}$.

Figure 7: Assignment (\%) of juvenile sole to the four natal sources based on the chemical variation in larval otolith signatures, by K-mear -lusi ering. For each sampling site the pie chart shows the relative contribution of each natal sourct (source $1: n=57$, source $2: n=16$, source 3: $n=85$, source $4: n=55$ ).

Table 1: Number of sole juver..'es analyzed for otolith elemental composition per sampling location and region (UK, Belg ar and Dutch Wadden Sea nursery grounds), including the date of sampling, geographical zoc. - Jinates and the sea surface temperature at the time of sampling (NA = Not Available).

Table 2: Classiı, ' ' Ju n accuracy and True Skill Statistics (TSS) of each sampling location when using the optimin: RF classifier for spatial discrimination of sole nurseries.

Table 3: Errors in re-assignment to sampling location (see Table 1) based on multi-elemental otolith edge signatures. Each row shows the average percentage of individual sole from each location assigned to each sampling location by the optimal Random Forest (RF) classifier (see Fig. 3). Numbers on the diagonal indicate individuals successfully re-assigned to their sampling location. Boxes group the sampling locations belonging to the same sampling region.

Table 4: Assignment of otolith settlement signatures to sampling location (see Table 1) using the Random Forest (RF) classifier optimal for sampling location discrimination. Numbers on the 
diagonal indicate individuals successfully re-assigned to sampling location as defined in Table 1. Boxes group the sampling locations belonging to the same sampling region.

\section{Supplementary material}

Supplementary Figure 1: Box plots of the standard length of the juveniles sampled for each of the four sampling regions. The solid line and the box correspond to the median and the interquartile range, respectively. Different letters indica ${ }^{2}$ groups of significantly different signatures based on Dunn's post hoc test $(p<0.05)$.

Supplementary Figure 2: Box plots of the eler.er. 'aı composition of the larval signatures of juvenile sole otoliths (see Suppl. Table 3). For $\epsilon_{2}$ h natal source, the solid line and the box correspond to the median and the interqu $\mathrm{rr}^{\mathrm{t}} \mathrm{l}$, range, respectively. Different letters indicate groups of significantly different si-nat. res based on Dunn's post hoc test $(p<0.05)$. The concentration of each element was ` srmalized to ${ }^{43} \mathrm{Ca}$ (the internal standard) and expressed in $\mu \mathrm{mol} \mathrm{mol}{ }^{-1}$, except for $\mathrm{Na} / \mathrm{Ca}$ a. $4 \mathrm{Sr} / \mathrm{Ca}$ (in $\mathrm{mmol} \mathrm{mol}^{-1}$ ) and $\mathrm{Pb} / \mathrm{Ca}$ (in pmol $\mathrm{mol}^{-1}$ ).

Supplementary Table $\mathbf{1}$ LI1, it Of Detection (LOD = 3 x standard deviation of the blanks) and percentage of missing w'ues for each element after setting negative LOD values to zero. The concentration of - du' element was normalized to ${ }^{43} \mathrm{Ca}$ (the internal standard) and expressed in umol mol ${ }^{-1}$, excu nt i ur $\mathrm{Na} / \mathrm{Ca}$, Fe/Ca and $\mathrm{Sr} / \mathrm{Ca}$ (in mmol mol ${ }^{-1}$ ) and $\mathrm{Pb} / \mathrm{Ca}$ (in pmol mol ${ }^{-1}$ ). Only elements in bolu were retained for final analyses.

Supplementary Table 2: Accuracy and precision of the ICPMS measurement of standard reference material (FEBS, NIST610, NIES) over all analysis sessions in this study (NA = missing value, $\mathrm{NCV}=$ Non Communicated Value). Recovery rate is the ratio of the measured concentration to the certified or reference concentration (in \%). Relative standard deviation is the ratio of the standard deviation to the average concentration (in \%). Elements in bold were retained for final analyses. 
Supplementary Table 3: (a) Mean elemental signature ( \pm standard deviation) for each sampling location (see Table 1, otolith sampling location signature). (b) Mean elemental signature ( \pm standard deviation) of the four natal sources identified by $\mathrm{K}$-means clustering based on the larval signature (source $1: n=57$, source $2: n=16$, source $3: n=85$, source $4: n=$ 55). For the list of sampling locations see Table 1. The concentration of each element was normalized to ${ }^{43} \mathrm{Ca}$ (the internal standard) and expressed in $\mu \mathrm{mol} \mathrm{mol}{ }^{-1}$, except for $\mathrm{Na} / \mathrm{Ca}$ and $\mathrm{Sr} / \mathrm{Ca}\left(\right.$ in $\mathrm{mmol} \mathrm{mol}^{-1}$ ) and and $\mathrm{Pb} / \mathrm{Ca}\left(\right.$ in $\mathrm{pmol} \mathrm{mol}{ }^{-1}$ ).

Supplementary Table 4: Spearman rank correlations ( $\operatorname{ink}:{ }^{*}$. able) obtained between body size

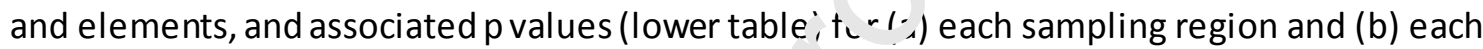
sampling location. Significant values (alpha leve, $u\urcorner$.5 ) are reported before (in bold) and after (underlined) Bonferroni correction for multipl? tc-ting. 
File: Delerue-Ricard_JSR_MS_20191127_tables1-4

Extensive larval dispersal and restricted movement of juveniles on the nursery grounds of sole in the Southern North Sea

Sophie Delerue-Ricard ${ }^{1,2}$, Audrey M. Darnaude ${ }^{3}$, Joost A.M. Raeymaekers ${ }^{4}$, Siv Hjorth Dundas ${ }^{5}$, Julie Skadal ${ }^{5}$, Filip A.M. Volckaert ${ }^{1}$, Audrey J. Geffen ${ }^{5,6}$

Table 1

\begin{tabular}{|c|c|c|c|c|}
\hline Region & $\begin{array}{l}\text { Sampling } \\
\text { location }\end{array}$ & Stat: $=n$ & Sampling size & Sampling date \\
\hline \multirow{2}{*}{$\begin{array}{l}\text { UK coast } \\
(n=32)\end{array}$} & UK & $\overline{G P R}_{1}:-$ & 19 & $14 / 03 / 2016$ \\
\hline & UK & -HAj07 & 13 & $01 / 08 / 2007$ \\
\hline \multirow{8}{*}{$\begin{array}{l}\text { Belgian coast } \\
(n=122)\end{array}$} & $\mathrm{B} 1$ & $\overline{\mathrm{BC}}, \overline{1 \mathrm{j} 14}$ & 16 & $15 / 09 / 2014$ \\
\hline & B2 & B02j13 & 15 & $10 / 09 / 2013$ \\
\hline & B2 & В03j13 & 21 & 28/08/2013 \\
\hline & B2 & В03j14 & 10 & $26 / 05 / 2014$ \\
\hline & B3 & B06j13 & 18 & 09/09/2013 \\
\hline & B3 & B06j14 & 17 & $16 / 09 / 2014$ \\
\hline & B4 & B08j14 & 17 & 10/10/2014 \\
\hline & B4 & ZANj07 & 8 & $01 / 10 / 2007$ \\
\hline \multirow{3}{*}{$\begin{array}{l}\text { Wadden Sea } \\
(n=51)\end{array}$} & $\bar{B}$ dge $\bar{c}$. & BALj06 & 14 & $01 / 08 / 2006$ \\
\hline & El, s-Dollard & NL1j14 & 16 & $16 / 09 / 2014$ \\
\hline & es iary & NL2j14 & 21 & $23 / 09 / 2014$ \\
\hline
\end{tabular}


Table 2

\begin{tabular}{ccccc} 
& UK & B1 & B2 & B3 \\
\hline Accuracy & 80.7 & 71.9 & 78.9 & 69.3 \\
TSS & 0.76 & 0.69 & 0.73 & 0.66 \\
\hline
\end{tabular}




\begin{tabular}{ccccccc|c|r}
\hline $\begin{array}{c}\text { Assigned } \\
\text { Location }\end{array}$ & UK & B1 & B2 & B3 & B4 & WA & Region & Average assic \\
$\begin{array}{c}\text { Sampling } \\
\text { Location }\end{array}$ & & & & & & & & \\
\hline UK & 73.6 & 0.4 & 4.7 & 8.7 & 1.2 & 11.5 & 73.6 & per sampling Ic \\
B1 & 6.5 & 34.7 & 15.3 & 6.2 & 32.4 & 4.9 & 88.5 & \\
B2 & 8.6 & 2.2 & 59.6 & 12.5 & 4.2 & 12.9 & 78.5 & \\
B3 & 14.3 & 0.9 & 26.0 & 41.8 & 0.7 & 16.3 & 69.4 & $76.1 \%$ \\
B4 & 6.6 & 13.9 & 9.4 & 1.4 & 41.8 & 26.8 & 66.6 & per sampling \\
WA & 5.4 & 0.6 & 6.5 & 6.2 & 1.2 & 80.1 & 80.1 &
\end{tabular}

Table 3 
Table 4

\begin{tabular}{ccccccc|c|c}
\hline $\begin{array}{c}\text { Assigned } \\
\text { location }\end{array}$ & & & & & & & & \\
$\begin{array}{l}\text { Settlement } \\
\text { signature at } \\
\text { the sampling } \\
\text { location }\end{array}$ & UK & B1 & B2 & B3 & B4 & WA & Region & A \\
\hline UK & 35.1 & 11.4 & 10.0 & 265 & 6.1 & 11.0 & 35.1 & \\
B1 & 3.8 & 25.0 & 6.3 & 3.7 & 31.3 & 0.0 & 96.2 \\
B2 & 0.0 & 19.9 & 56.0 & 11.2 & 4.3 & 8.5 & 91.5 \\
B3 & 2.9 & 17.0 & 17.4 & $4 i .7$ & 14.2 & 2.9 & 94.3 \\
B4 & 8.0 & 8.0 & 20.0 & 16.0 & 40.0 & 8.0 & 84.0 \\
WA & 0.6 & 5.1 & 11.6 & $-\frac{16.0}{3.8}$ & 3.8 & 75.1 & 75.1 & \\
\hline
\end{tabular}




\section{Highlights:}

- In the North Sea, juvenile otolith signatures differ at the regional scale $(100 \mathrm{~km})$

- Movement appears to be limited once the juveniles have reached a nursery ground

- Local nursery areas receive larvae from four chemically distinct natal sources

- Mixed larval contributions to nurseries point to an extensive larval dispersal 